\title{
Depreciation of human capital: a sectoral analysis in OECD countries
}

\author{
Valeria Lentini \\ Department of Economics, University of Costa Rica, San Pedro, Costa Rica, and \\ Gregorio Gimenez \\ Faculty of Economics and Business, University of Zaragoza, Zaragoza, Spain
}

Received 5 July 2018 Revised 6 April 2019 Accepted 4 July 2019

\begin{abstract}
Purpose - The purpose of this paper is to investigate which sectors are more vulnerable to human capital depreciation, with an emphasis on potential differences in skills and in ICT intensities.

Design/methodology/approach - The authors estimate an extended Mincerian earnings equation based on Neuman and Weiss's (1995) model using the EU-KLEMS international database for 15 sectors for the period from 1980 to 2005. The authors also test structural ruptures in earnings and human capital depreciation in the labor market per decade controlling by technological intensity.

Findings - Human capital depreciation ranges from 1 to 6 percent. It is mainly significant in skill-intensive sectors regardless of the sector's technological intensity. The analysis of structural breaks shows that human capital value indeed changed from decade to decade. It even appreciated in low skill-intensive sectors in the 1980 s and in the high skill-intensive during the 1990s. Appreciation though, was mainly skill-biased.

Research limitations/implications - Information about on-the-job-training and non-cognitive skills that can also affect human capital depreciation are not included due to lack of data.

Practical implications - To prevent human capital from depreciating in particular sectors and periods educational systems should provide the tools for ongoing lifelong learning at all skills levels. Education is subject to dynamic effects that should be addressed to increase the potential benefits of technological change.

Originality/value - First, instead of using cross-section analysis which is considered to be a pitfall in studying the depreciation of knowledge, the authors observe its dynamic on a longitudinal basis. Second, the international macro-sectoral approach goes beyond limited micro-sectoral analysis in certain countries.
\end{abstract}

Keywords Technology, Education, ICT, OECD, Human capital depreciation

Paper type Research paper

\section{Introduction}

Human capital decreases when workers' skills do not meet labor market needs. This reduction, called human capital depreciation, can be due to a deterioration of their skills (e.g. from ageing) or to technological and organizational market changes. Depreciation can also result from demographic changes when younger, higher skilled workers pressure the labor supply in sectors where skills are more important than experience.

The combination of changing worker and labor market profiles leads to obsolescence of workers' skills and a mismatch in supply-demand profiles. Obsolescence affects worker market value, measured by income, which therefore depreciates. The problem is particularly relevant for individuals and societies from OECD countries. In these economies, in which skills and innovation are key competitive factors, the ageing population is becoming a concern.

Neuman and Weiss (1995) proposed to estimate human capital depreciation using an extended version of the Mincerian earnings equation. It incorporates an interaction term between schooling and experience, which allows to unentangle it from experience depreciation. This model has been used in literature with cross-sectional data on workers' skills. However, the use of cross-sectional analysis can be considered a pitfall in studying the

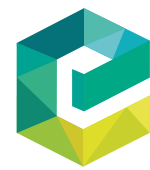


depreciation of knowledge, because analyzing the effect of human capital over time requires a longitudinal data set that is not always available.

Another characteristic of human capital depreciation studies has been the almost exclusive approach of focusing on high-tech vs low-tech industries. Literature has conceded more importance to the impact of technological change in high-tech industries than in others. The objective of this research is to analyze the human capital depreciation at a sectoral level, independently of its technological intensity.

This essay has three methodological novelties. First, we use sectoral macro-panel data from the OECD allowing us to adopt a dynamic perspective that addresses the technical drawback of the cross-sectional micro-level analysis. In this sense, the use of macro-level regressions could help to close the gap in the literature. Second, our macro-sectoral approach provides a broad panorama of human capital depreciation, with an international view that transcends individual sectors or countries. We control by countries' technological intensity to take into account heterogeneity and its evolution. Finally, we test structural ruptures by decade and sector.

We analyze the period from 1980 to 2005. In these years, the debate over information and communication technologies (ICT) jobs' complementarity vs replacement gained strength with the spread of new technologies available in the 1980s and 1990s. There is evidence that until the late 1980s technological changes in developed economies were mostly skill-biased and contributed to inequality (see Autor et al., 1998; Goldin and Katz, 2008; Goos et al., 2009; Acemoglu and Autor, 2011).

However, during the 1990s, the increasing demand for high-skilled workers was accompanied by a relative decline in demand for middle-skilled rather than low-skilled workers. This phenomenon was called labor market polarization (Autor and Dorn, 2013; Goos et al., 2009). By studying structural breaks, this paper contributes to the literature during those decades of technological transition, in our case the loss of market value of workers' skills (i.e. human capital depreciation). The inclusion of structural breaks shows that human capital value indeed changed between decades.

In the analysis of the productive sectors with harmonized data of $12 \mathrm{OECD}$ countries, we employed econometric techniques that provide robust estimates in the presence of endogeneity as well as spatial and temporal dependencies of an unknown order.

Unlike other findings, our results indicate that aggregated human capital depreciation is independent of sectors' skill level and ICT intensity. It is significant and ranges from 1 to 6 percent. These results imply that workers are exposed to reduced earnings, which is relevant from a social policy point of view and calls for continuing education to maintain the value of human capital at all skills levels. Another important finding was that appreciation of human capital also occurred and was mainly skill biased.

The rest of the paper is organized as follows. Section 2 discusses previous human capital depreciation research and theory; Section 3 describes the data; Section 4 explains the baseline model; Section 5 discusses the results; and Section 6 offers concluding comments.

\section{Theoretical framework and background literature: human capital depreciation}

\subsection{The concept}

Human capital relates to a broad concept of skills and conditions (i.e. education, talent, health and experience) that determine productivity and earnings. Becker (1964) and Ben-Porath (1967) originated the framework model that relates human capital with education and productivity, and conceived the definition of schooling or education attainment as a proxy for human capital.

When human capital depreciates, returns diminish. The main reason for this depreciation is obsolescence that can be classified according to two general causes (Van Loo et al., 2001; De Grip and Van Loo, 2002; De Grip, 2006). 
Technical or internal human capital obsolescence. This first type refers to a loss of skill caused by the natural ageing process, a worker's physical deterioration, illness or injury and skill atrophy from a lack of, or insufficient, use of skills. Although ageing is natural, not all individuals in different industries (even within industries) and countries (because of local working conditions) face an identical distribution of internal depreciation. The process may affect people at a different "rate" and jobs and occupations may wear on workers unevenly[1]. Some skills may also deteriorate or become outdated owing to career interruptions and unemployment. This obsolescence, although different per individual, is assumed to be intrinsic to human nature.

Economic or external obsolescence. External obsolescence is attributable to a worker's environment. It occurs alongside systematic changes in the production process, the labor market, the organization of tasks or the introduction of new technologies. These changes transform individual qualification and tasks demands for the job (see Autor et al., 2003; Michaels et al., 2014; Frey and Osborne, 2017; Graetz and Michaels, 2017).

The difference between internal and external depreciation is that internal depreciation reduces a worker's qualifications and earnings (economic value), while external depreciation only diminishes the worker's value in the labor market. A worker's skills value drops when the demand for those skills are no longer relevant, even if the skills themselves still exist. The external depreciation can vary according to market conditions, technological changes and intensity and workers' adaptability.

External human capital depreciation becomes particularly relevant in a context of accelerated penetration of new technologies. Rosen (1975) and Ben-Porath (1967) were among the first to study this kind of depreciation. Younger workers are beneficiaries of new technologies since they grew up with recent knowledge of the technology and were adapted to it at school (see also Janssen and Backes-Gellner, 2009).

Human capital depreciates when technological change makes a worker's knowledge outdated, incorrect or less generalized than in earlier times. Hence, we refer to depreciation as a relative productivity reduction that diminishes the value of workers' skills in the labor market. In this context, human capital loses value when the worker's knowledge relates to technologies that are no longer used.

\subsection{External human capital depreciation and technological progress, by skills or sectors}

Workers are exposed to different degrees of technology depending on the sector in which they work or the task they perform, and their qualifications are linked to these tasks. Higher qualified or skilled workers will hold jobs in which they have a comparative advantage, generally assumed in literature as being in technology-intensive or high-tech sectors or in industries that demand knowledge-based tasks. Technological progress will therefore not affect every worker of the labor market in the same way.

There are contradictory findings on the effect of worker's educational attainment on human capital depreciation. There is supporting evidence that higher skills are associated with higher obsolescence and depreciation rates (e.g. Mincer, 1974; Neuman and Weiss, 1995; Murillo, 2011), and that depreciation is lower in workers with elementary skills or education because they do not undergo many changes over time. It is argued that changes occur in more innovative and technology-oriented tasks performed by high-skilled workers.

On the other hand, there are studies that demonstrate that education reduces human capital depreciation because, when environment and technology change, a better-educated worker will regain this capital more quickly (Gould et al., 2001; Van Loo et al., 2001).

Empirical evidence supports both arguments. Economic theory does not have a canonical model about the impact of technological evolution, which can be of different types depending on the characteristics of the sectors, regions and time periods analyzed. 
To address the research on how technology affects human capital, studies have focused the analysis within or by sectors. To this end, they have proposed different industry classifications in order to identify the high-tech sectors, the technology-producing industries (product-oriented) or the technology-intensive sectors (see Sabadash, 2013; and OECD, 2016 for an explanation). Our research investigates depreciation controlling by ICT intensity. A novelty from a macro perspective.

\subsection{Measurement of human capital depreciation, dependent variables}

The estimation of human capital depreciation has mainly focused on the evolution of two labor market variables: unemployment and earnings. The first vein of studies calculates the probability of becoming unemployed or dropping out of the labor market (see Van Loo et al., 2001; Allen and De Grip, 2007; Frey and Osborne, 2017) dependent on technology or market changes.

In the second approach, earnings evolution analyses have looked at skill premiums and relative wage changes according to workers' skills. Some have focused on the inequalities they create in the labor market and society (e.g. Goos and Manning, 2007; Autor and Dorn, 2013). Others have estimated human capital depreciation using an extended version of the basic Mincerian equation (e.g. Neuman and Weiss, 1995; Weber, 2014; Castillo, 2016). This paper uses the aforementioned methodology of estimation for three reasons: it allows for differentiating internal from external depreciation; working with earnings facilitates sectoral comparisons; and unemployment and inequality have been examined as depreciation indicators in the 1980s and 1990s, but the loss of value of human capital in the labor market has rarely been analyzed. Despite these explanations, using earnings as a proxy for human capital value is not without certain drawbacks. In some job markets, depreciation may be underestimated when there is downward wage rigidities and legislation of minimum wage.

\subsection{Empirical evidence based on sectoral and skills analysis}

The extent to which different sectors are subject to technological change has varied over time and across countries, and empirical evidence of human capital depreciation analyzed by sectoral technological intensity is scarce and contradictory.

One reason for this is that the classification of sectors by technological intensity has employed different criteria. For example, Neuman and Weiss (1995) divide industry sectors into high-tech and low-tech firms with data from Israel's 1983 worker census in order to compare human capital depreciation in each sector. Firms are classified as high-tech if they contract engineers and technicians, have capital less than six years old, and carry out research and development (R\&D) activities. The authors test whether the effect of interaction between workers' level of education and work experience has a more negative impact on earnings when they are employed in high-tech rather than low-tech firms. They conclude that depreciation is relatively more important in the high-tech sectors, which hire higher skilled workers (i.e. electronics/transport equipment, chemicals/minerals and metals).

We can find another example of sector classification with data concerning a developed country, Spain, in Murillo (2011). She defines sectors according to their technological intensity, using their R\&D expenditure, following the OECD (2003) criteria. Additionally, she classifies manufacturing firms into four groups: low; medium-low; medium-high, and high technological content. By using pseudo-panel data created using two cross-sectional datasets from Spain in 1995 and 2002, she also finds that technology threatens higher skilled human capital more than the medium skilled, but regardless of the sector's technological intensity, and depreciation is not statistically significant for low-skilled workers.

Using their particular sectoral criteria, other authors obtain less straightforward conclusions from human capital depreciation according to skill attainment. Arrazola et al. (2005) analyze data 
from 1994 in the Spanish labor market and find no evidence of heterogeneous depreciation by education level. They observe other variables that explain depreciation such as employer sector (private or public), workers' recent unemployment spells, and whether they undertook training courses. On the other hand, Groot (1998) finds contradictory results in Great Britain and the Netherlands. Depreciation by skill level is heterogeneous in the British sample (from the 1990s) and it is higher for lower skilled workers. In the Dutch survey (from the mid-1980s), he finds that the rate of depreciation increases with years of education.

Sectoral analyses by technological intensity using cross-sectional data have also been pursued in Latin America, for example, Soto et al. (2007) and Castillo (2015) for Mexico and Castillo (2016) for Chile, Colombia, Mexico and Peru. The results concur with those that find human capital depreciation to be skill biased in developed countries.

\subsection{Technological change and earnings in the 1980s and the 1990s}

Prior the 1980s, in developed countries, the rate of growth of the relative supply of skills narrowed educational wage differentials. Around 1980, workers' skills continued to grow at a slower pace (Goldin and Katz, 2008). There is a consensus in the literature that in the 1980s and onwards, the supply of skilled workers was absorbed by the labor market driven by the adoption of computers and information technology. Nevertheless, overall wage inequality also increased in a number of countries, evidencing uneven impacts of technology, depending on worker's skills profiles (Goos and Manning, 2007; Goos et al., 2009).

The computer revolution, as it was usually called, began with the commercial use of computers in the 1960s, which then continued throughout the development of the internet and e-commerce in the 1990s (Frey and Osborne, 2017). Still in the 1970s and 1980s, computers were a very small fraction of the capital stock that had a measurable impact, but during the 1980s and 1990s, the cost of computers rapidly decreased and its share increased. At the same time, bar code scanners and cash machines spread across retail and financial industries. The first personal computers with word processing and spreadsheet were introduced in the early 1980s. After 1995, the web and e-commerce rapidly developed and settled by 2005. This type of technological changes had an impact in productivity and introduced innovations in buying and selling, and in the learning-by-using process. Inventions since 2000 extended to entertainment and communication, to create small, smart and capable devices, but did not particularly concentrate in production processes as in the 1980s or 1990s (Gordon, 2012).

Consequently, there is evidence that between 1980 and 2005 the occupational structure of the labor market was reshaped (Goos et al., 2009). For example, the share of US labor in service occupations grew by 30 percent after having been flat or declining in the three decades prior (Autor and Dorn, 2013). This trend impacted wages, worker's occupation reallocations and increased returns on cognitive abilities (Ingram and Neumann, 2006).

\subsection{Measures of technological intensity}

Direct measures of technological intensity are not available across countries and years. Different indicators have therefore been used for measuring technology with varying results, depending on the indicator. An example of the differences among the indicators can be observed in Acemoglu and Restrepo (2017). They analyze the technological impacts on employment and wages in the USA between 1990 and 2007 with two different technologyrelated variables: information technology capital growth and the increased use of robots. While ICT capital growth is observed in electronics, education, construction and services, robotization is experienced mainly in automotive-plastic-chemicals and metal-products. The two technology-related variables changes did not occur in the same sectors nor did they have an even impact on labor. 
Early literature analyzing technological intensity effects on the labor market used R\&D expenditures as the primary variable. More recently, ICT data available in databases like EU-KLEMS have also been used. For example, Michaels et al. (2014) constructs instrumental variables with ICT data to demonstrate polarization in the labor market of the USA, Japan, and nine European countries from 1980 to 2004.

In this paper, we observe the sectors' ICT intensity by calculating the ICT stock share as a proportion of total capital stock. In the next section, we examine the sectors by technological intensity and workers' skills profile.

\section{Data and descriptive statistics}

Our data comes from the EU-KLEMS data set (O’Mahony and Timmer, 2009), funded by the European Commission. It is designed to measure economic growth, productivity, employment creation, capital formation and technological change at an industry level for all European Union member states. Our sample of 12 countries is conditioned by the availability of the skill composition variables needed for this research[2]. It covers the period 1980-2005 for Australia, Austria, Czech Republic, Denmark, Finland, Germany, Italy, Japan, Spain, The Netherlands, UK and the USA[3].

The sectors analyzed in this study can be observed in Table I. The data about the whole economy is directly available in the original database. All together, we work with 15 sectors plus the whole economy. Our final sample has 284 observations. The years included in the analysis (up to 2005) were restricted by the availability of the EU-KLEMS data set.

We constructed our panel data from the following variables.

\subsection{Earnings (e)}

Average hourly earnings per person engaged (employees, self-employed and family workers) expressed in 1995 euros. The earnings variable was not available as such, so it was necessary to structure it from the labor compensation (LAB), labor services (LAB_QI) and number of persons engaged (EMP) variables.

\subsection{Education (edu)}

Average years needed to complete the education level held by the engaged person. EU-KLEMS provides data on three different skill groups: high (college and above), middle (high school, some college education and people with nonacademic professional degrees) and low (less than high school).

The database provides information on the share of engaged persons by three age bands (15-29, 30-49, 50 and higher). To estimate accumulated years of education, the share of each group was calculated and weighted, assuming 17 years for high-skills (maximum educational attainment), 12 years for medium skills and 7 years for low skills.

\subsection{Experience (exp)}

Average years of net potential experience of engaged persons. We constructed this variable by computing the difference between the age of individuals (midpoint of the age band) and the years of education, minus 6 years (pre-formal education).

Table I breaks down the data by sector and Table II by country. Workers with higher education are disproportionately distributed in: education, health/social work, real-estate/ renting/business-activities, public-administration and financial-intermediation (column 6). In the education sector, almost half of the workers are university graduates. A second group of sectors, with a higher than average share of middle-skilled workers, includes: electricity/gas/ water, post/telecommunications and wholesale/retail-trade. The remaining group of sectors includes those with the lowest educational attainment. 


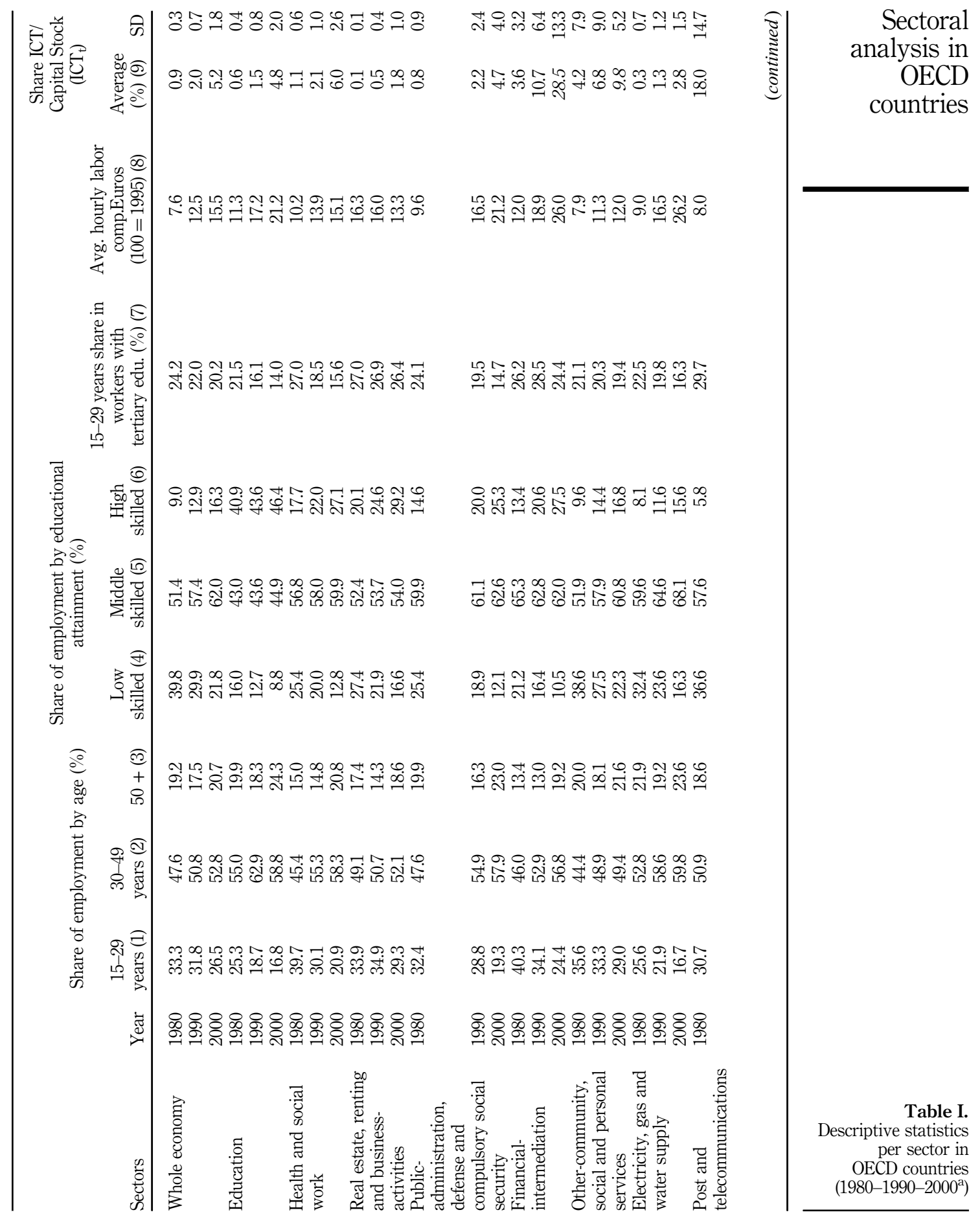



ฌั

m m 密雚 苟苟 请

Ұ L⿻

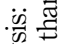
苗. 용

กิ 焉 กิ่ 焉贺言

๓

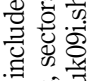

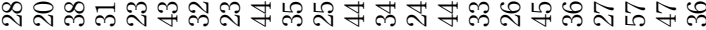

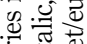




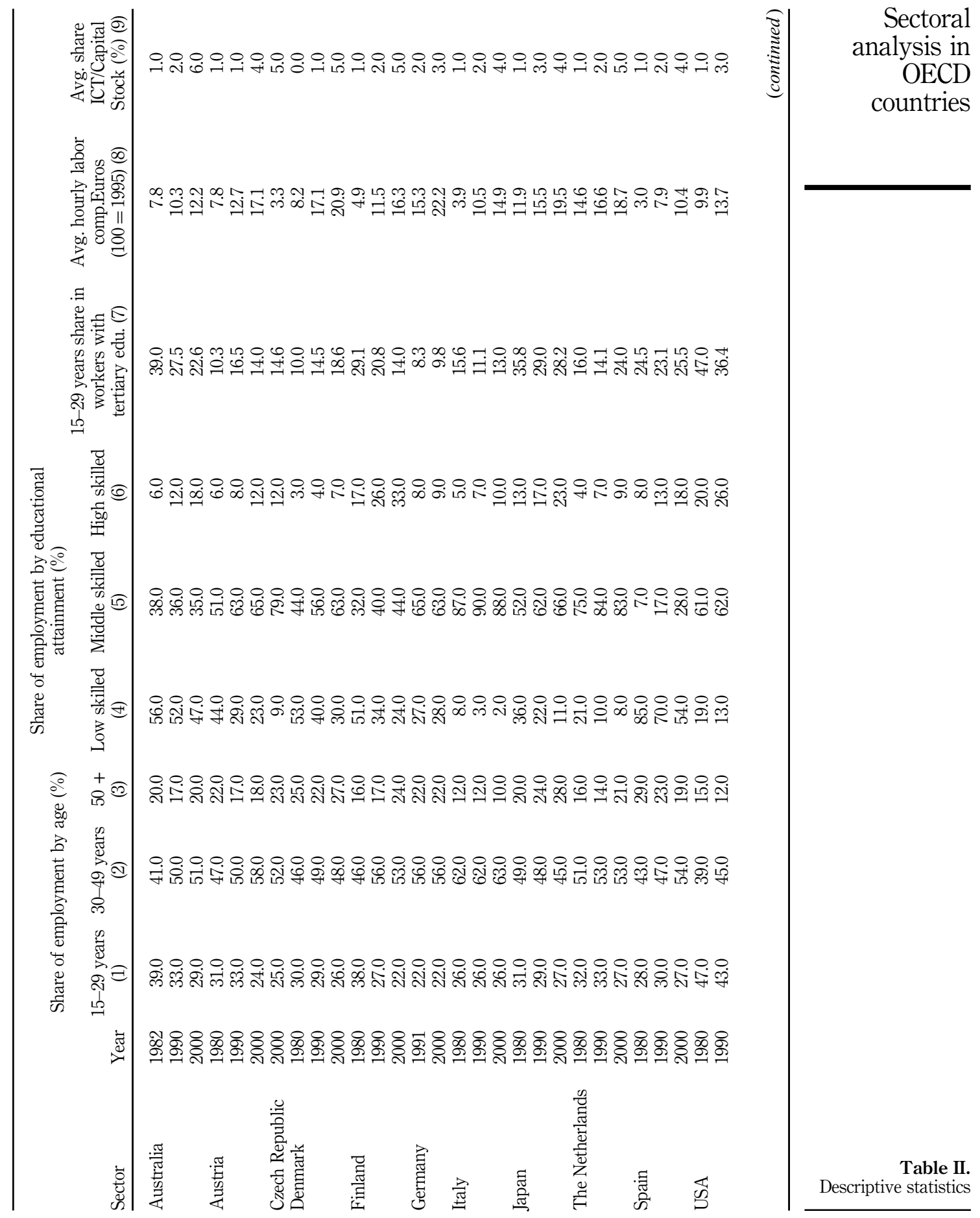


IJM

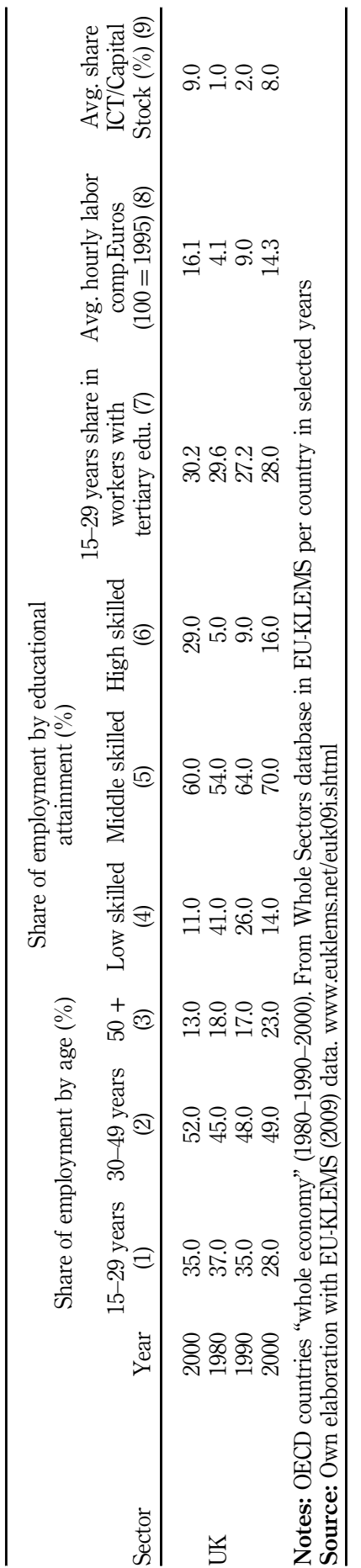

Table II. 
All sectors and countries have experienced a skill upgrade as indicated by the share of workers with higher education in column 6: on average, the share increased from 9.0 percent in 1980 to 16.3 percent in 2000 and, by country, Australia, Finland, Japan, Spain and USA reached a higher proportion.

Despite the sectors' unequal changes in skill upgrading and countries labor market differences, the ranking of sectors with regard to skill intensity in 1980 was quite similar twenty-five years later. This might suggest that sectors play an invariable role in clustering skills profiles (Michaels et al., 2014).

Due to the demographic structural changes, the share of young skilled workers with higher education within the high-skilled workers' category declined throughout those decades (column 7). In the whole economy, in 1980, almost a quarter of the high-skilled workers were 15-29 years old, but in 2000 the proportion diminished to 20 percent. The decline was particularly noticeable in agriculture-hunting-forestry-fishing and in mining/quarrying.

Almost all sectors show an increase in the average hourly labor compensation during the period. For the whole economy, real earnings more than double from $1980(€ 7.6)$ to 2000 (€15.5) (column 8).

Column 9 shows that in many sectors and countries in the 1980s, the ICT intensity was close to zero and grew dramatically in the next decade. The change, in absolute terms, was higher than the average in these seven sectors: post/telecommunications, financialintermediation, wholesale/retail-trade, other-community/personal-services[4], construction, manufacture and transport/storage. The latter four are also low-skill-intensive.

It is worth noting that not all sectors operate the same in the different countries. The ICT intensity per sector was variable within countries. The most homogenous were manufacture, education, financial-intermediation and wholesale/retail-trade. However, from the 1980s to the 1990s, all the countries have reduced their sectors' ICT stock share heterogeneity, showing a convergence in their mode of production.

\section{The model: Neuman and Weiss's earning function}

The profitability of individuals' investment in education is commonly estimated through the standard Mincerian earning function (Mincer, 1974). This function fits a semi-log ordinary least squares regression. The natural logarithm of earnings $(e)$ is the dependent variable, explained by the years of formal education $(e d u)$ and net potential years of labor market experience (exp) quantified as age $-e d u-6$ :

$$
\ln (e)=\beta_{0}+\alpha_{1} e d u_{i}+\alpha_{2} \exp _{i}+\delta_{1} \exp _{i}^{2}+\varepsilon_{i},
$$

where $i=$ country.

The coefficient $\alpha_{1}$ is usually interpreted as the average individual's returns on education, and $\alpha_{2}$ as the returns on their experience. Experience depreciation is represented by $\delta_{1}$, the coefficient of experience squared, but education depreciation is omitted in the Mincerian equation. This omission might generate specification bias of returns on education, which is non-static over time.

Neuman and Weiss (1995) add the human capital depreciation rate coefficient $\delta_{2}$ to the Mincerian function (1). This is obtained as a single parameter interacting with the schooling and experience variables $\left(e^{2} u e x p_{i t}\right)$ in the following equation:

$$
\ln (e)=\beta_{0}+\alpha_{1} e d u_{i t}+\alpha_{2} \exp _{i t}+\delta_{1} \exp _{i t}^{2}+\delta_{2} e d u \exp _{i t}+\varepsilon_{i t},
$$

where $i=$ country and $t=$ year.

The introduction of this term $\left(\delta_{2}\right)$ makes it possible to differentiate depreciation related either to worker's ageing or his more outdated education. The authors emphasized that their model does not focus on the peak or the inflection point from which human capital starts 
depreciating but instead it concentrates on the profile shift. They argue that the peak might move or become less pronounced over time, making "this approach more appropriate for panel studies where peaks may not be found" (p. 950). Although Neuman and Weiss (1995) refers to $\alpha_{1}$ as human capital returns, it would not be a properly comparable term with it in Equation (1), because its value is conditioned by the introduction of the interaction effect (Card, 2001; Heckman et al., 2008; Hanushek and Woessmann, 2012).

Our macroeconomic approach overcomes three main inconveniences of using Mincer's equation with cross-sectional data in a particular moment to study depreciation of workers' skills that certainly might vary over time. First, although age-cohorts represent the progression of human capital depreciation quantified in the analysis, the assumed conditions are static. Data on depreciation estimators come from earnings that are reported at a specific moment and under specific economic and production conditions. Therefore, data depreciation estimations are valid for a particular time.

Second, with this approach we cannot separate real changes (i.e. due to modifications of workers' characteristics and market-determined wage levels) from behaviors that mutate over time (the cohort effect).

Third, the cross-section approach assumes that individuals' lifetime earnings will follow the same pattern over time. The basic Mincerian equation assumes perfect certainty about future earnings in a static economic environment and production context, with an invariant occupational structure, and technological capital and an organization of production without improvements or evolution.

Additionally, to capture the possible effect that ICT intensity might have on our coefficient of interest, $\delta_{2}$, we calculate the equation controlling by ICT intensity per year, $i c t_{t}$.

Finally, in order to analyze the structural break between decades we introduce the dummy variable since 1990 where $\delta_{3}$ is a differential intercept coefficient, telling us how much $\ln (e)$ has changed, on average, since 1990 (or a particular year in the early 1990s). We also study the joint effect of since90 with the eduexp (depreciation) variable as expressed in Equation (3) to see if not only the intercept but also the slope of the regression changes:

$$
\begin{aligned}
\ln (e)= & \beta_{0}+\alpha_{1} e d u_{i t}+\alpha_{2} \exp _{i t}+\alpha_{3} i c t_{t}+\delta_{1} \exp _{i t}^{2}+\delta_{2} e d u e x p_{i t} \\
& +\delta_{3} \text { since } 1990_{i}+\delta_{4} \text { since } 1990_{i} \cdot \text { eduexp }_{i t}+\varepsilon_{i t} .
\end{aligned}
$$

In linear panel data, the residuals commonly present heteroscedasticity and time correlation due to the combination of cross-section and time series. To address this situation, we first tested the panel data serial correlation using the method proposed by Wooldridge (2002) and implemented by Drukker (2003). Second, we calculated heteroscedasticity using a modified Wald statistic, following Greene (2000), to avoid sensitiveness to the assumption of normality of the standard Wald test errors. This test is preferable in unbalanced panels like ours. Third, we performed a Pesaran (2004) cross-sectional dependence (CD) test on the residuals of the regression model. The $x t s c c$ Stata routine module developed by Hoechle (2007) let us calculate fixed effects (within) regression with CD and spatial correlation and robust Driscoll and Kraay-DK (1998) standard errors.

Driscoll and Kraay (1998) propose a nonparametric covariance matrix estimator that offers robust standard errors in the presence of heteroscedasticity and autocorrelation of error terms of the type AR (unknown order) and facilitates robust estimations under spatial and time dependence of unknown magnitude. As described in Gimenez et al. (2017), this estimator is convenient for the analysis of cross-sectional units that might share common characteristics, as might be the case for the countries we studied.

We tested the spatial correlation of the regression with the CD Pesaran's test (2004). Time dependence was also tested with different lags (up to six). Due to autocorrelation of one or 
the other, or both (spatial and time), the estimators were calculated with DK standard errors which also have asymptotic properties for panels such as ours in which $T>N$. The assumption of independence among countries would be invalidated in the presence of spatial autocorrelation.

Finally, to test endogeneity that can affect estimator consistency due to the potential correlation between regressors and the error term, we used an instrumental variable (IV) estimator: the average of schooling lagged one year. Endogeneity was detected in two samples for the 1980-2005 period: whole economy, and real-estate/renting/businessactivities but when we analyze the two subperiods (1980-1989 and 1990-2005), endogeneity disappears, so there is no need for IV.

\section{Results}

Table III shows the results of the estimation of the extended Neuman and Weiss equation. The eduexp coefficient is significant in the case of the whole economy in the 25-year period (column 1). When the coefficient has a negative sign, it is interpreted as human capital depreciation. At the sectoral level, human capital depreciation is observed either in the low skill-intensive sectors or in those in the middle. It reached 5.7 percent annually in mining/ quarrying; 4.0 percent in manufacture; 3.1 percent in wholesale/retail-trade; and 1.1 percent in other-community/personal-services.

The eduexp coefficient shows a positive sign in some of the sectors. Although the literature has not expressed it as "appreciation," the result would make sense if there is on-the-job training or reinvestment in education that maintains or upgrades the value of human capital as might be the case for the whole economy. In the whole economy, human capital appreciation was also consistent in the analysis per country. An alternative explanation for human capital appreciation in particular sectors might be the shortage of high-skilled younger workers as in the agriculture-hunting-forestry-fishing sector. Its new entrants had lower education levels, which might have reduced the pressure in favor of experienced workers in the sector.

The results confirm that economies have gone through a structural break since 1990, when the expansion of ICT share of capital stock began to grow faster. In Table III, the specific year of significant structural changes in the intercept and the slope are shown. As expected, all sectors show a significant change in workers' earnings in the $1990 \mathrm{~s}$ (the intercept). Additionally, changes in the slope coefficient from the interaction of the dummy variable with the eduexp variable are also statistically significant in all except for real-estate/renting/ business-activities. In some sectors, changes in human capital depreciation do not always go along with a structural change in earnings. That is the case for whole economy, health/social work and construction. Since all sectors but real-estate/renting/business-activities present a structural break from the 1980s to the 1990s in human capital value, the analysis per decade proves to be relevant.

Table IV shows the split by decade of the eduexp coefficient (columns 2 and 3). It evidences heterogeneous variation of depreciation by sector. Human capital depreciation in the 1980s was significant in education, public-administration and post/telecommunications; and in the $1990 \mathrm{~s}$ again in education. In both periods, human capital depreciation was skilled biased. Is in the period as a whole in which less skill-intensive sectors depreciate (wholesale/ retail-trade, manufacture and mining/quarrying).

Wholesale/retail-trade presented the highest appreciation coefficient (8.8 percent in the 1980s, column 4). To this regard, Bessen (2015) mentions that in 1980 the number of cashiers grew despite the introduction of bar code scanners in supermarkets. Technological change was speeding up, but the supply of workers was keeping the pace. The parallel paces in that period might explain the lack of consequences on human capital depreciation, as well as other unobservable variables such as on-the-job training. 


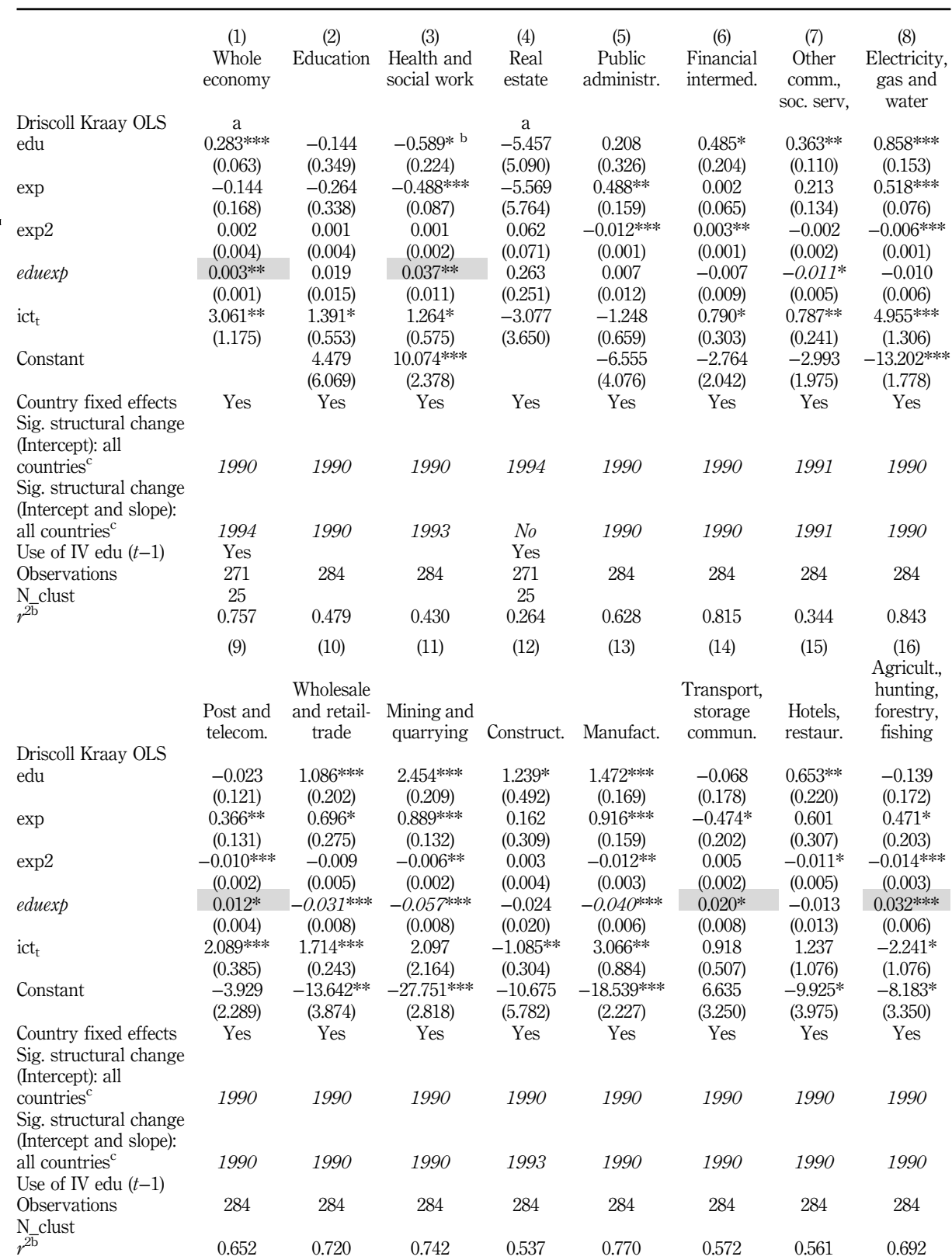

Table III.

Estimation of Neuman and Weiss earning function for a pool of OECD countries (1980-2005)
Notes: Standard errors in parenthesis. Italic means significant with negative sign (depreciation), and gray means significant but with positive sign (appreciation); Countries pooled by sector: Australia, Austria, Czech Republic, Denmark, Finland, Germany, Italy, Japan, Spain, The Netherlands, UK and the USA; ${ }^{a}$ Estimators using IV under the presence of endogenous regressors; ${ }^{\mathrm{b}} r^{2}$ reported when no IV where used is the $r^{2}$ within; ${ }^{c}$ the structural breaks were also tested excluding Germany and Czech Republic (that only have data for the $90 \mathrm{~s}$ ), but results, except for the whole economy in which the intercept and slope presented the change one year before (1993) were robust. $* p<0.1 ; * * p<0.05 ; * * p<0.01$ 
Sectors

Whole economy

Education

Health and social work

Real estate, renting and business-activities

Public-administration, defense and compulsory social security

Financial-intermediation

Other-community, social and personal services

Electricity, gas and water supply

Post and telecommunications

Wholesale and retail-trade

Mining and quarrying

Construction

Manufacture

Transport, storage and communications

Hotels and restaurants

Agriculture, hunting, forestry and fishing

\section{Countries}

Australia $^{\mathrm{a}}$

Austria

Denmark $^{\mathrm{a}}$

Czech Republic ${ }^{\mathrm{a}}$

Finland

Germany $^{\mathrm{a}}$

Italy

Japan

The Netherlands

Spain $^{\mathrm{a}}$

UK

USA

$\begin{array}{lcc}0.003^{* *} & 0.008^{* * *} & 0.001 \\ 0.019 & -0.063^{* * *} & -0.023^{*} \\ 0.037^{* *} & 0.052^{* *} & 0.081^{* * *} \\ 0.263 & 0.034 & 0.027^{* * *} \\ 0.007 & -0.027^{*} & 0.021^{*} \\ -0.007 & 0.017^{* *} & 0.015^{* * *} \\ -0.011^{*} & -0.023 & -0.028 \\ -0.010 & 0.033^{* * *} & -0.011 \\ 0.012^{*} & -0.038^{* * *} & 0.019^{* *} \\ -0.031^{* * *} & 0.088^{* *} & 0.005 \\ -0.057^{* * *} & -0.015 & -0.026 \\ -0.024 & -0.028 & -0.004 \\ -0.040^{* * *} & -0.014 & -0.004 \\ 0.020^{*} & 0.027^{*} & 0.009 \\ -0.013 & -0.003 & -0.007 \\ 0.032^{* * * *} & 0.034^{* *} & 0.063^{* * *}\end{array}$

\begin{tabular}{ccc}
-0.657 & 0.084 & 0.004 \\
$0.019^{*}$ & $0.014^{*}$ & $-0.021^{* * *}$ \\
$0.134^{* *}$ & 0.017 & $0.048^{* * *}$ \\
na & na & $1.188^{*}$ \\
\hline$-0.040^{* * *}$ & $0.032^{* *}$ & $-0.033^{* * *}$ \\
na & na & -2.173 \\
0.304 & 0.018 & $0.226^{* * *}$ \\
$0.036^{* * *}$ & $0.033^{* * *}$ & $0.056^{* * *}$ \\
$0.038^{* * *}$ & 0.027 & $0.020^{* * *}$ \\
$0.183^{*}$ & $0.041^{* * *}$ & 0.010 \\
\hline 0.008 & -0.021 & -0.016 \\
0.004 & -0.003 & 0.001
\end{tabular}

Notes: Italic means significant with negative sign (depreciation), and gray means significant but with positive sign (appreciation). Countries pooled by sector: Australia, Austria, Czech Republic, Denmark, Finland, Germany, Italy, Japan, Spain, The Netherlands, UK and the USA; OLS with FE-DK standard errors, with ICT intensity controls; nd, No available data. ${ }^{a}$ Estimators using IV under the presence of endogenous regressors. $* p<0.1 ; * p<0.05 ; * * * p<0.01$

\section{Sectoral analysis in OECD countries}

Another result to highlight is that 4 out of 7 sectors previously identified as the high ICT intensive show expected depreciation rates for the whole period (other-community/personalservices, wholesale/retail-trade and manufacture) or in part of it (post/telecommunications). Depreciation was also observed in ICT-non intensive sectors such as education and public-administration.

These results are in line with those of Castillo (2016) in which manufacture and service sectors were found to be more vulnerable to depreciation for Chile, Colombia, Mexico and Peru. The results also coincide with Janssen and Backes-Gellner (2009), who found that the human capital of workers performing knowledge-based tasks suffers more depreciation than that of individuals performing experience-based tasks, although they do link it to technological content. Surprisingly, in our work, the eduexp coefficient is significantly positive in some unskilled-intensive sectors in the 1980s, though mainly in skill-intensive sectors in the 1990s.

There is a lack of consensus in the literature on the magnitude of human capital depreciation. In Spain, Murillo (2011) finds maximum depreciation rates of 3 percent in highskilled occupations in construction and business services sectors and in middle-skilled 
occupations in education and health/social work. Castillo (2016) reports human capital depreciation of up to 4 percent in the tertiary sector of Chile, and Groot (1998) finds rates of 11-17 percent per year in Great Britain and the Netherlands for workers in general, with data from the late 1980s and early 1990s. In our analysis, the individuals for which human capital depreciates more rapidly in the 1980s were in education with a rate of 6.3 percent, but in the "1990s its workers" vulnerability was lower, 2.3 percent per year. For the whole period, the maximum level was observed in mining/quarrying with 5.7 percent. In the analysis per country, Finland was the only country in which human capital depreciated (3.3 percent), specifically in the 1990s, and it is the country with the highest proportion of high-skilled workers in the year 2000 (Table II).

We express depreciation of human capital as a vulnerability. The results show that not only skilled or technological intensive sectors are vulnerable to external human capital depreciation. The earning's and human capital depreciation's structural breaks from the 1980 s to the 1990s were confirmed for the majority of the sectors.

\section{Conclusions}

Earnings from labor are the primary source of income in households, and in OECD countries human capital investment has offered the promise of high earnings in the labor market. Rapid technological changes since the 1980s caused concerns about the impact of technology on unemployment and inequality in the labor market but rarely about its relation to human capital depreciation or appreciation.

The analysis of human capital value becomes increasingly important in times in which the rate of change in technology is growing while human capital is accumulating. This paper analyses the depreciation of human capital in the whole economy and 15 sectors in 12 OECD countries using the EU-KLEMS panel data set for the period from 1980 to 2005. Our comparison of depreciation rates between sectors, on the one hand, and between decades, on the other, gives some interesting results.

First, we confirmed that human capital depreciation is heterogeneous by sector and it is significant mainly in skill-intensive sectors regardless of its technological intensity. Secondly, human capital also "appreciates" mainly in sectors with a preponderance of lowskilled workers in the 1980s, a possible explanation is that in those sectors human capital became more valuable. However, in the 1990s it was skilled biased. Lastly, structural breaks occurred with human capital value and earning during the 1980s and the 1990s.

As there were sector aggregation issues, this kept us from analyzing subsector dynamics; our results encourage an extension when particular subsector data are available as well as to include other regions and time periods. Additionally, the period of analysis (up to 2005) was restricted by the availability of data, but the study can be extended when comparable data is updated. Furthermore, a valuable input to the analysis would be information about ongoing training by sector to measure if it offsets human capital depreciation.

Initial education is subject to dynamic effects that should be studied to understand its value for productivity. Clearly, a rethinking of education should unequivocally be at the forefront of policy responsibility in order to promote continuous upgrading and revalue of human capital. The continuing trend of technological change brings a permanent decrease in the cost of ICTs, imposing a challenge for workers (if ICTs substitute jobs) or an opportunity (if ICTs complement jobs).

One way to address human capital depreciation would be to offer initial education that trains students to keep learning and to "learn to learn." Educational systems should guarantee that the quality and type of education provide the tools for ongoing lifelong preparation. We all need to start action on lifelong learning. Training throughout working life and up- and re-skilling of the workforce at all levels restores human capital lost or diminishes the rate at which human capital erodes, and might be a source of appreciation. 


\section{Notes}

Sectoral

1. We appreciate the suggestions of the reviewers of our first manuscript on clarifying this point.

2. Other countries in the EU-KLEMS database, such as Canada, Poland and Slovakia, lacked information on skill shares; and France, Portugal, Ireland and others lacked labor information. Belgium, Hungary and Korea were also excluded for not having ICT data.

3. The following countries have a shorter data period: Australia (1982-2005), Czech Republic (1995-2005), Hungary (1995-2005) and Germany (1991-2005).

4. Other-community, social and personal services aggregates industries with heterogeneous ICT intensity (for example Recreational, cultural and sporting activities vs Media activities) but there was no variability in labor composition data to be able to separate the analysis.

\section{References}

Acemoglu, D. and Autor, D. (2011), "Skills, tasks, and technologies: implications for employment and earnings", Handbook of Labor Economics, Vol. 4, pp. 1043-1171.

Acemoglu, D. and Restrepo, P. (2017), "Robots and jobs: evidence from US labor markets", NBER, Working Paper No. 23285.

Allen, J. and De Grip, A. (2007), "Skill obsolescence, lifelong learning and labor market participation", Mimeo and Research Centre for Education and the Labor Market, Maastricht.

Arrazola, M., de Hevia, J., Risueño, M. and Sanz, J.F. (2005), “A proposal to estimate human capital depreciation: some evidence for Spain”, Hacienda Pública Española - Revista de Economía Pública, Vol. 172 No. 1, pp. 9-22.

Autor, D. and Dorn, D. (2013), "The growth of low skill service jobs and the polarization of the US labor market”, American Economic Review, Vol. 103 No. 5, pp. 1553-1597.

Autor, D., Levy, F. and Murnane, R. (2003), "The skill content of recent technological change: an empirical exploration”, Quarterly Journal of Economics, Vol. 118 No. 4, pp. 1279-1333.

Autor, D., Katz, L.F. and Krueger, A.B. (1998), "Computing inequality: have computers changed the labor market?”, Quarterly Journal of Economics, Vol. 113 No. 4, pp. 1169-1213.

Becker, G.S. (1964), Human Capital: A Theoretical and Empirical Analysis with Special Reference to Education, 3rd ed., National Bureau of Economic Research, New York, NY.

Ben-Porath, Y. (1967), "The production of human capital and the life cycle of earnings", Journal of Political Economy, Vol. 75 No. 4, pp. 352-365.

Bessen, J. (2015), Learning by Doing: The Real Connection Between Innovation, Wages, and Wealth, Yale University Press, New Haven and London.

Card, D. (2001), "Estimating the return to schooling: progress on some persistent econometric problems", Econometrica, Vol. 69 No. 5, pp. 1127-1160.

Castillo, A. (2015), "Retornos y depreciación del capital humano, un análisis empírico para México durante 2011-2014”, Conference Paper September 2015, Saint Thomas University, Bogotá.

Castillo, A. (2016), "Depreciación del capital humano en la Alianza del Pacífico durante 2007-2014", Ciencias Económicas, Vol. 34 No. 1, pp. 9-46.

De Grip, A. (2006), "Evaluating human capital obsolescence", working papers, ROA, Research Centre for Education and the Labor Market, Maastricht.

De Grip, A. and Van Loo, J. (2002), “The economics of skills obsolescence: a review”, in De Grip, A., Van Loo, J. and Mayhew, K. (Eds), The Economics of Skills Obsolescence (Research in Labor Economics, Vol. 21), Elsevier Science, Amsterdam, Boston, London, New York, Oxford and Paris, pp. 1-26.

Driscoll, J.C. and Kraay, A.C. (1998), "Consistent covariance matrix estimation with spatially dependent panel data", Review of Economics and Statistics, Vol. 80 No. 40, pp. 549-560. 
Drukker, D.M. (2003), “Testing for serial correlation in linear panel-data models”, Stata Journal, Vol. 3 No. 2, pp. 168-177.

Frey, C.B. and Osborne, M.A. (2017), "The future of employment: how susceptible are jobs to computerization?", Technological Forecasting \& Social Change, Vol. 114 No. C, pp. 254-280.

Gimenez, G., Pastor-Pérez, M.P. and Malacara-Hernández, H.M. (2017), "Factores de innovación en los estados de México. ¿A qué se deben las diferencias entre estados con mayor y menor dinamismo innovador?", Investigación Económica, Vol. 76 No. 302, pp. 131-164.

Goldin, C. and Katz, L.F. (2008), The Race between Education and Technology, Harvard University Press, Cambridge, Massachusetts and London.

Goos, M. and Manning, A. (2007), "The rising polarization of work in Britain", The Review of Economics and Statistics, Vol. 89 No. 1, pp. 118-133.

Goos, M., Manning, A. and Salomons, A. (2009), "Job polarization in Europe", American Economic Review, Vol. 99 No. 2, pp. 58-63.

Gordon, R. (2012), "Is US economic growth over? Faltering innovation confronts the six headwinds", Working Paper No. 18315, National Bureau of Economic Research, Cambridge.

Gould, E., Moav, O. and Weinberg, B. (2001), "Precautionary demand for education, inequality and technological progress.", Journal of Economic Growth, Vol. 6 No. 4, pp. 285-315.

Graetz, G. and Michaels, G. (2017), "Is modern technology responsible for jobless recoveries?", American Economic Review, Vol. 107 No. 5, pp. 168-173.

Groot, W. (1998), "Empirical estimates of the rate of depreciation of education.", Applied Economics Letters, Vol. 5 No. 8, pp. 535-538.

Hanushek, E. and Woessmann, L. (2012), "Schooling, educational achievement, and the Latin American growth puzzle", Journal of Development Economics, Vol. 99 No. 2, pp. 497-512.

Heckman, J., Lochner, L. and Todd, P. (2008), "Earnings functions and rates of return", Journal of Human Capital, Vol. 2 No. 1, pp. 1-31.

Hoechle, D. (2007), "Robust standard errors for panel regressions with cross-sectional dependence", The Stata Journal, Vol. 7 No. 3, pp. 281-312.

Ingram, B.F. and Neumann, G.R. (2006), "Returns to skill", Labour Economics, Vol. 13 No. 1, pp. 35-59.

Janssen, S. and Backes-Gellner, U. (2009), "Skill obsolescence, vintage effects and changing tasks", Applied Economics Quarterly (formerly: Konjunkturpolitik), Vol. 55 No. 1, pp. 83-103.

Michaels, G., Natraj, A. and van Reenen, J. (2014), "Has ICT polarized skill demand? Evidence from eleven countries over twenty-five years", Review of Economics and Statistics, Vol. 96 No. 1, pp. 60-77.

Mincer, J. (1974), Schooling, Experience, and Earnings, National Bureau of Economic Research, New York, NY.

Murillo, I.P. (2011), "Human capital obsolescence: some evidence for Spain.”, International Journal of Manpower, Vol. 32 No. 4, pp. 426-445.

Neuman, S. and Weiss, A. (1995), "On the effects of schooling vintage on experience-earnings profiles: theory and evidence”, European Economic Review, Vol. 39 No. 5, pp. 943-955.

O'Mahony, M. and Timmer, M.P. (2009), "Output, input and productivity measures at the industry level: the EU KLEMS database.”, Economic Journal, Vol. 119 No. 538, pp. 374-403.

OECD (2003), "OECD Science, Technology and Industry Scoreboard”, OECD, Paris.

OECD (2016), "Working party on measurement and analysis of the digital economy", Background Paper for Ministerial Panel 4.2, 'Skills for a digital world' OECD, Cancún.

Pesaran, M.H. (2004), "General diagnostic tests for cross section dependence in panels", Working Papers in Economics No. 0435, University of Cambridge, Faculty of Economics, Cambridge.

Rosen, S. (1975), "Measuring the Obsolescence of Knowledge", in Juster, F.T. (Ed.), Education, Income, and Human Behavior, NBER, New York, NY, pp. 199-232. 
Sabadash, A. (2013), "ICT-induced technological progress and employment: a happy marriage or a dangerous liaison? A literature review", JRC-IPTS Working Papers No. JRC76143, Institute for 39 Prospective and Technological Studies, Joint Research Centre, Sevilla.

Soto, G., Barceinas, R. and Raymond, J.C. (2007), Depreciación del capital humano. Una aproximación sectorial: el caso de México, Universidad Autónoma Metropolitana.

Sectoral
analysis in
OECD
countries

Van Loo, J., De Grip, A. and De Steur, M. (2001), "Skills obsolescence, causes, and cures”, International Journal of Manpower, Vol. 21 Nos 1/2, pp. 121-137.

Weber, S. (2014), "Human capital depreciation and education level", International Journal of Manpower, Vol. 35 No. 5, pp. 613-642.

Wooldridge, J.M. (2002), Econometric Analysis of Cross Section and Panel Data, The MIT Press, Cambridge, MA.

\begin{abstract}
About the authors
Valeria Lentini is Lecturer in the Department of Economics, University of Costa Rica. A recipient of the British Council Scholarship for the MA Degree in Development Economics at Sussex University, she currently is pursuing a $\mathrm{PhD}$ at the University of Zaragoza. Her academic interests lie in the fields of development economics and education, for which she has coordinated several research studies. She is an experienced team leader and market research analyst, and has designed primary research for projects throughout Latin America. Valeria Lentini is the corresponding author and can be contacted at: valeria.lentini@ucr.ac.cr

Gregorio Gimenez has a degree in Economics (with honors) and a $\mathrm{PhD}$ from the University of Zaragoza, where he is currently working as Associate Professor. His main areas of research are economics of growth and development, with special emphasis on the role of human capital and education. He has been in charge of several research projects and supervises $\mathrm{PhD}$ theses on these topics. He has published articles in various international journals of prestige such as Technovation, Applied Economics or Revista de Educación.
\end{abstract}

For instructions on how to order reprints of this article, please visit our website: 